\title{
A study on the genus Phaecasiophora Grote (Lepidoptera: Tortricidae: Olethreutinae) from the mainland of China, with descriptions of five new species
}

\author{
Haili Yu \& Houhun Li*
}

Yu, H. \& Li, H. 2006: A study on the genus Phaecasiophora Grote (Lepidoptera: Tortricidae: Olethreutinae) from the mainland of China, with descriptions of five new species. - Entomol. Fennica 17: 34-45.

Fourteen species of Phaecasiophora Grote from the Chinese Mainland are treated, including five new species ( $P$. supparallelica sp. n., P. levis sp. n., $P$. curvicosta sp. n., P. lushina sp. n., and $P$. similithaiensis sp. n.) and three new species records for China. Phaecasiophora leechi is transferred from subgenus Megasyca to subgenus Phaecasiophora, and a new synonym of it, viz. P. obligata Kawabe, is proposed. Photographs of the adults, genitalia of the new species, and the species with new synonyms are provided. A key to the species from the Chinese Mainland based on genitalia is given.

Haili Yu and Houhun Li, College of Life Sciences, Nankai University, Weijin Road 94, Tianjin, 300071, China; correspondent author's e-mail: lihouhun @nankai.edu.cn

Received 12 April 2005, accepted 12 July 2005

\section{Introduction}

Phaecasiophora was erected by Grote (1873) based on the males having a hind tibia heavily tufted with scales. The genus was extensively studied by Heinrich (1926), Diakonoff (1959, 1973) and Razowski (1989). It is characterized by male genitalia with the uncus completely absent, socius pending and haired, and saccular bristles poorly developed. Based on the male genitalia, Diakonoff (1959) divided Phaecasiophora into three subgenera, Phaecasiophora Grote, Megasyca Diakonoff and Sycacantha Diakonoff. Later, Diakonoff (1966) elevated Sycacantha Diakonoff to the generic status, which we follow in the present paper.

The genus is represented by thirty described species worldwide, three of which occur in North America (Walker 1863, Grote 1873, Henrich 1931), three in Africa (Walsingham 1891, Diako- noff 1983a), and the remainder in South and East Asia (Walsingham 1900, Meyrick 1907, 1909, 1920, 1931, Diakonoff 1959, 1973, 1983b, Kawabe 1982, 1986, 1987, 1989, 1993, Kawabe et al. 1992, Kuznetsov 1997, 2001, Byun et al. 1998, Liu \& Li 2002). In China, nine species have been previously reported, including four species endemic to Taiwan. The present paper deals with 14 species from the mainland of China, with five species described as new to science and three recorded for the first time from this country. Phaecasiophora obligata Kawabe is proposed to be a synonym of Phaecasiophora leechi Diakonoff.

\section{Material and methods}

Specimens used in this study were collected by light trap in thirteen forest reserves and five 
mountain villages in South China, where vegetation forms are mainly hardwood forest or mixed conifer and hardwood forest. The description of wing patterns follows Brown \& Powell (1991) refined by Baixeras (2002), and the genitalia dissections follows Li \& Zheng (1996). The type specimens and other specimens are deposited in the Insect Collection, College of Life Sciences, Nankai University, Tianjin, China.

\section{Results}

Phaecasiophora Grote, 1873

Phaecasiophora Grote, 1873: 90

Type species: Sericoris mutabilana Clemens $=$ Sciaphila confixana Walker [by subsequent designation of Fernald (1908)]

Key to the species of Phaecasiophora from Mainland of China based on genitalia

1. Socius short, membranous, not pointed

- Socius long, sclerotized, pointed apically

2. Cucullus not constricted at base P. leechi Diakonoff

- Cucullus constricted at base

3

3. Cucullus with ventral margin concave at basal $1 / 3$, bearing a long thorn at base; cornuti a sturdy cluster of thorns, 0.57 times of aedeagus in length $\quad$ P.decolor Diakonoff

- Cucullus with ventral margin not concave, lacking thorns at base; cornuti a cluster of short spines, less than 0.3 times of aedeagus in length

4. Socius triangular or oval

- Socius somewhat quadrate, with apex projected at middle and lateral angle

6

5. Socius triangular; corpus bursae oval, slightly flat P. attica (Meyrick)

- Socius oval; corpus bursae long, with length about 2 times its width P.pertexta (Meyrick)

6. Cucullus expanded outward medially 7

- Cucullus not expanded at median part 8

7. Tegumen broad; cucullus with median portion 1.6 times of base in breadth P. levis sp.n.

- Tegumen narrow; cucullus with median por- tion 1.3 times of base in breadth

P. lushina sp.n.

8. Tegumen dorsally triangular; cucullus with apical part broader than basal part

P. curvicosta sp.n.

- Tegumen dorsally semicircular; cucullus with apical part as broad as basal part

P. supparallelica $\mathrm{sp} . \mathrm{n}$.

9. Aedeagus slender, length about 3.5 times its width and 0.58 times of valva in length, with two distinct dentations at apex; cornuti absent

P. pyragra Diakonoff

- Aedeagus broad, length about 1.8-2.2 times its width and less than 0.35 times of valva in length, without dentations at apex; cornuti present

10. Aedeagus with minute spines in apical part; cornuti a strong thorn, a little shorter than aedeagus P.obraztsovi Diakonoff

- Aedeagus without minute spines; cornuti composed of a cluster of spines, less than half of aedeagus in length

11. Valva with cucullus constricted medially P. similithaiensis sp. $\mathrm{n}$.

- Valva with cucullus not constricted medially

12. Cucullus with base 12 times of middle in width, carrying a thorn, about 0.3 times of cucullus in length; socius conical, apical part produced into a horn; lamella antevaginalis large, lamella postvaginalis concave at lateral sides P. cornigera Diakonoff

- Cucullus with base dilated to a large prominence, nearly 2 times of middle in width, lacking thorns; socius ear-like; lamella antevaginalis relatively small, lamella postvaginalis not concave at lateral sides $\quad 13$

13. Cucullus length 6.5 times its width, with a semicircular prominence at base; lamella antevaginalis with upper edge rounded; ductus bursae slightly narrow

P. fernaldana Walsingham

- Cucullus length 7.5 times its width, with an oblong-oval prominence at base; lamella antevaginalis with upper edge slightly concave; ductus bursae wide

P. walsinghami Diakonoff 


\subsection{Subgenus Phaecasiophora Grote, 1873}

Phaecasiophora Grote, 1873: 90

Type species: Sericoris mutabilana Clemens = Sciaphila confixana Walker (by subsequent designation)

The subgenus Phaecasiophora is characterized by the socius being rounded, membranous, hairy and bristled. Members of the subgenus are rather uniform in appearance, and forewings possess indistinct markings and white or white dusted stria from costal strigula five between median fascia and postmedian fascia and extending obliquely to tornus.

\subsubsection{Phaecasiophora (Phaecasiophora) attica (Meyrick, 1907)}

Eucosma attica Meyrick, 1907: 137 (ð, , +, India: Assam)

Argyroploce attica: Meyrick, 1935: 61 (Tienmushan, W. China)

Olethreutes attica: Clarke, 1958: 487, plate 242, figure 2-2a (ô genit.)

Phaecasiophora (Phaecasiophora) attica: Diakonoff, 1959: 170, plate II, figure 4 ( genit., Burma)

Distribution. China (Zhejiang, Yunnan, Taiwan), Vietnam, Burma, Thailand, India, Russia.

Remarks. Meyrick $(1935,1938)$ recorded this species from Mt. Tianmu, Zhejiang Province and Lijiang, Yunnan Province. Kawabe, et al. (1992) reported it from Taiwan.

\subsubsection{Phaecasiophora (Phaecasiophora) decolor Diakonoff, 1983}

Phaecasiophora (Phaecasiophora) decolor Diakonoff, 1983b: 45, figure 32 (o genit.), plate 7, figure 27 (Adult, Indonesia: Sumatra)

Material examined. China: $1 \partial^{\top}$, Daozhen (29 $32^{\prime}$ N, 10740’ E), Guizhou Province, 1,300 m a.s.l., 19.VIII.2004, leg. Yunli Xiao.

Distribution. China (Guizhou), Indonesia.

Remarks. This species can be easily distinguished from other described species of the genus by the forewing being very broad, strongly arched at 1/3 length of costa, straight along termen, and occupied by four transverse fasciae that reach the termen. Slight variations in the male genitalia are found in the specimen collected from China: valva broader and the spines composing cornuti longer and thicker than those from Indonesia. However, the specimens from both localities are identical in the superficial characters. This species is recorded for the first time from China.

\subsubsection{Phaecasiophora (Phaecasiophora) leechi} Diakonoff, 1973 (Figs. 1a, 2a, 3a)

Phaecasiophora (Megasyca) leechi Diakonoff, 1973: 120-121, plate 13. (o genit., China: Foochau)

Phaecasiophora obligata Kawabe, 1993: 227228; figures 1, 13 (Adult, §̋ genit., China: Taiwan) syn. $n$.

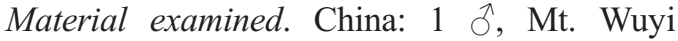
(265' N, 116 $42^{\circ}$ ' E), Fujian Province, 1,000 m a.s.1., 26.V.2004, leg. Haili Yu. 1 đे, Mt. Tianmu (30²6' N, 119³4' E), Zhejiang Province, $500 \mathrm{~m}$ a.s.1., 16.VIII.1999, leg. Houhun Li. 1 đ, Lichuan (30¹8’ N, 108 56' E), Hubei Province, 700 m a.s.1., 30.VII.1999, leg. Houhun Li. 5 ふ઼̄ 1 ㅇ, Mt. Jiuhua $\left(30^{\circ} 23^{\prime} \mathrm{N}, 117^{\circ} 48^{\prime} \mathrm{E}\right)$, Anhui Province, 5.-9.VIII.2004, leg. Jiasheng $\mathrm{Xu}$ and

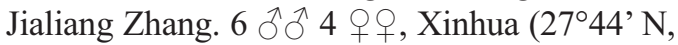
$111^{\circ} 18^{\prime}$ E), Hunan Province, 9.-11.VIII.2004, leg. Yunli Xiao.

Description. Adult (Fig. 1a) as illustrated; male genitalia (Fig. 2a) as illustrated; female genitalia (Fig. 3a) as illustrated.

Distribution. China (Fujian, Zhejiang, Anhui, Hubei, Hunan, Taiwan).

Remarks. Based on both male and female specimens collected from different localities of China, we found the female of P. obligata resembles $P$. leechi both in appearance and in the genitalia. In both species, the median fascia on the forewing is divided into three blotches with margins that are completely or partly white. In the female genitalia, the lamella postvaginalis has distinct, short, thick edged lateral appendages, the colliculum is straight, long and strong; the ductus bursae is long, and the corpus bursae is elongate without signa. Furthermore, descriptions of $P$. 
Fig. 1. Adults of Phaecasiophora spp. - a. $P$. leechi Diakonoff,, .

- b. P. supparallelica sp. n., paratype $\delta^{\Uparrow}$.

-c. P. levis sp. n., paratype $\sigma^{2}$. - d. P. curvicosta sp. n., holotype $\delta^{\lambda}$. - e. P. lushina sp. n., holotype $\widehat{\jmath}$. - f. P. similithaiensis sp. n., holotype $\hat{O}$.
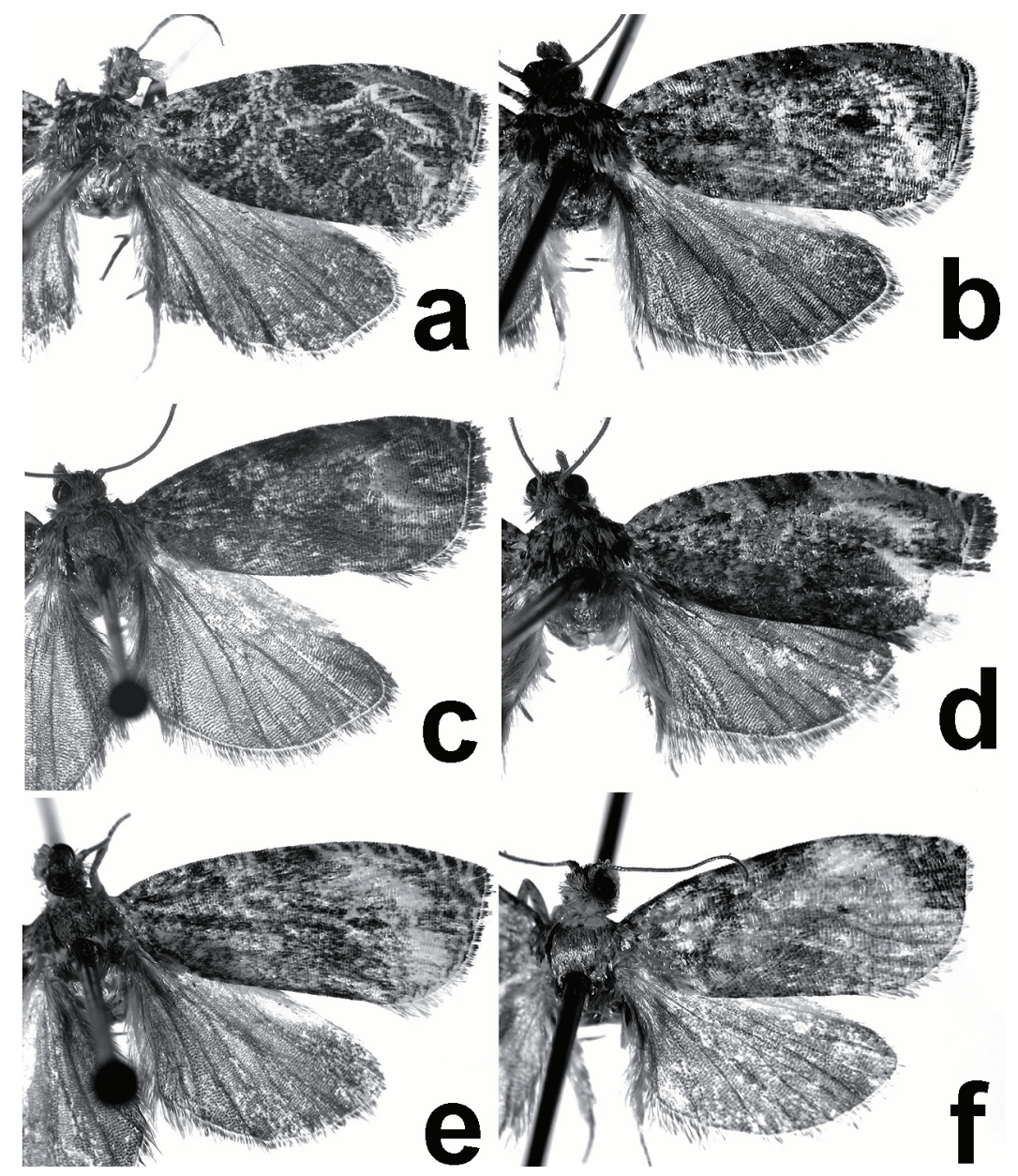

leechi and $P$. obligata were based on a single female and a single male specimen, respectively. The type localities of $P$. obligata (Taiwan) and $P$. leechi (Foochau [Fuzhou], Fujian Province) are geographically close. Based on the superficial characters as well as the characters of both male and female genitalia, we think the two species are conspecific and $P$. obligata should be a synonym of $P$. leechi. In addition, $P$. leech $i$ was placed in the subgenus Megasyca by Diakonoff(1973), but we think this species should belong to subgenus Phaecasiophora based on the study of the male genitalia.

\subsubsection{Phaecasiophora (Phaecasiophora) pertexta (Meyrick, 1920)}

Argyroploce pertexta Meyrick, 1920: 351 (ふ, ㅇ, Sikkim)
Olethreutes pertexta: Clarke, 1958: 535, plate 266 figure I-Ic (lectotype design., wings, $q$ genit.).

Phaecasiophora (Phaecasiophora) pertexta: Diakonoff, 1973: 116

Phaecasiophora guttulosa Diakonoff, 1973: 117-118, figure 180 (ð̋ genit., India, Sikkim)

Material examined. China: 1 $\widehat{\jmath}$, Mt. Tianmu (30²6’ N, 119³4' E), Zhejiang Province, 1,140 m a.s.1., 17.VIII.1999, leg. Houhun Li.

Distribution. China (Zhejiang, Fujian), India, Sikkim, Nepal.

Remarks. Clarke (1958) provided the photographs of the wings and female genitalia. Robinson et al. (1995) proposed $P$. guttulosa Diakonoff as a synonym of this species. Liu \& Li (2002) recorded $P$. guttulosa from Fujian Province, China. 

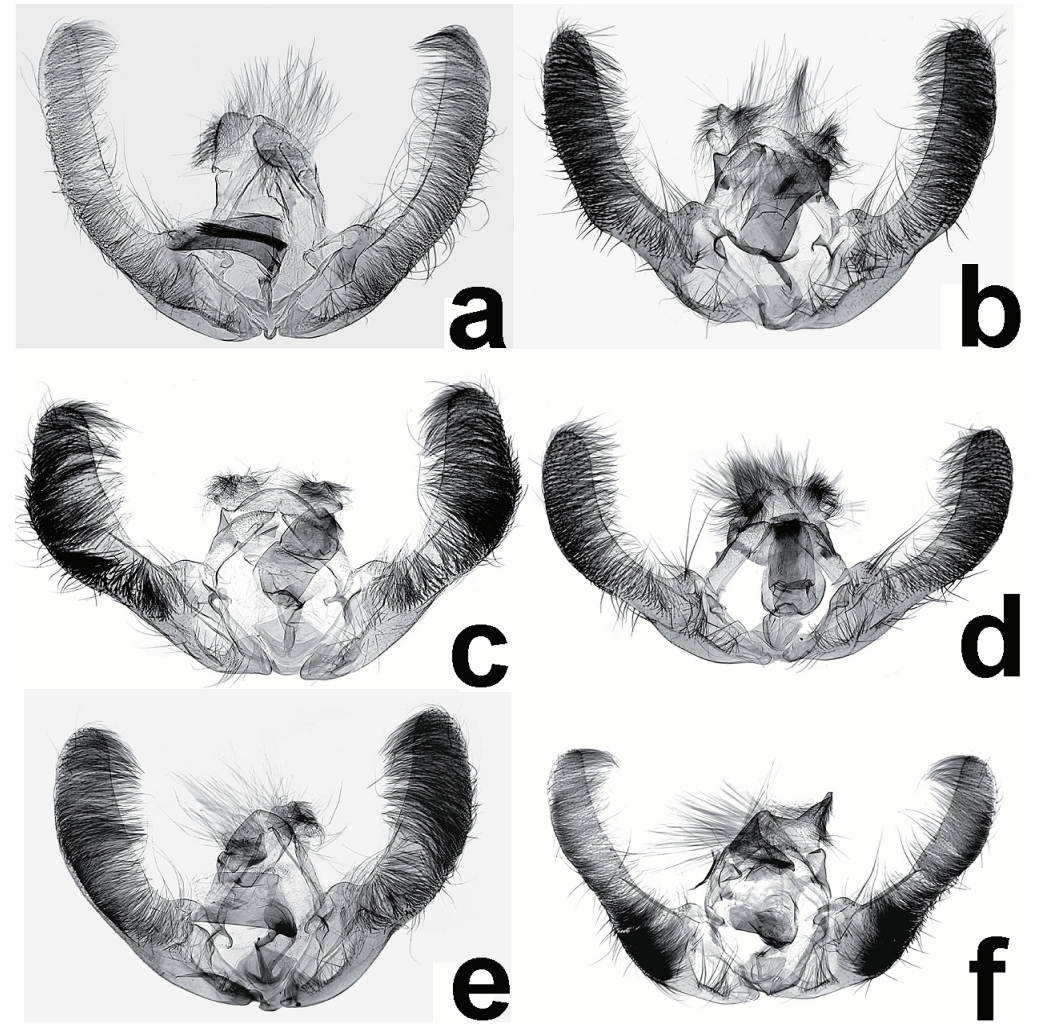

Fig. 2. Male genitalia of Phaecasiophora spp. - a. P. leechi Diakonoff (slide no. YHL04774). -b. P. supparallelica sp. n., holotype (slide no. YHL04256). - c. P. levis sp. n., holotype (slide no. YHL04106). - d. P. curvicosta sp. n., holotype(slide no. YHL04261). - e. P. lushina sp. n., holotype (slide no. ZAH03162). -f. P. similithaiensis sp. n., holotype (slide no.

YHL04314).

\subsubsection{Phaecasiophora (Phaecasiophora) supparallelica sp. n. (Figs. 1b, 2b)}

Type material. Holotype $\hat{\jmath}$, China: Daozhen (293'ㅅ N, 107 $40^{\prime}$ E), Guizhou Province, $600 \mathrm{~m}$ a.s.1., 29.V.2004, leg. Shulian Hao, genitalia slide no. YHL04256. Paratype: 1 गे, Zhangjiajie (2949’ N, 110²6’ E), Hunan Province, $650 \mathrm{~m}$ a.s.1., 8.VIII.2001, leg. Houhun Li and Xinpu Wang.

Diagnosis. This new species resembles $P$. jubilans Diakonoff in the male genitalia, but can be easily separated from the latter by the socius being plate-like in shape with its apical part sunken at the outer $1 / 3$, whereas the socius is triangular without a sunken outer part in the latter species. In appearance the two species can be easily distinguished from each other by forewing with the median fascia serrate at the distal margin and the prominent striae from costal strigulae five and six broad, silvery white in P. jubilans. While in P. supparallelica sp. $\mathrm{n}$., the median fascia in the forewing is broken, its distal margin is indistinct, and the stria from the costal strigula five is narrow and less prominent.

Description. (Fig. 1b): Forewing length 8.1$8.5 \mathrm{~mm}$. Vertex coarse, grayish brown anterior of antenna and deep brown posteriorly. Antenna reaching $1 / 2$ length of forewing, brown. Labial palpus ascending; basal segment white; median segment white to pale grey; terminal segment small, grayish brown. Thorax deep brown, sparsely sprinkled with ochreous scales. Foreleg slightly pale grey; midleg with tibia pale yellow, covered by thorn-like scales, set with a pale brown dot at bases; hindleg white, tibia strongly broadened by long and white scales, with two hair pencils from base, one white, longer and thin, the other pale grey, shorter and relatively thick; all legs with tarsal subsegments pale brown on lateral side. Forewing with costa slightly arched throughout; apex blunt; termen straight; upperside ground color brown, suffused with ochreous, denser before $2 / 3$ length of wing and below costa; costa with nine pairs of strigulae from base to $R_{4}$, the strigulae are distributed as follows: four pairs (strigulae one to four) between the base of wing and the point where the Sc meets the costa, two 
pairs (strigulae five and six) between $\mathrm{Sc}$ and $\mathrm{R}_{1}$, one pair (strigula seven) between $R_{1}$ and $R_{2}$, one pair (strigula eight) between $R_{2}$ and $R_{3}$, one pair (strigula nine) between $R_{3}$ and $R_{4}$; each pair of strigulae with a leaden (silvery) stria extending obliquely; strigulae one and two pale ochreous, with striae extending backward to base of dorsum, indistinct, strigulae three and four pale ochreous, with striae extending to dorsum between $1 / 3$ length and midlength, discontinuous, the distal five pairs of strigulae white, stria from strigula five extending obliquely to tornus, striae from strigulae six, seven and eight becoming confluent, extending along distal margin of postmedian fascia to tornus, stria from strigula nine extending to $M_{1}$ at termen, striae from strigulae five, six to eight, and nine separated from each other by ochreous spots; basal fascia and subbasal fascia deep brown, indistinct, broken by pale ochreous and ochreous spots; median fascia represented by a large deep brown spot on costa and a blackish brown spot on distal part of discal cell, the rest area with large umbrae; postmedian fascia deep brown, intermixed with white-ochreous, extending to middle of termen; preterminal fascia indistinct; terminal fascia expressed by a small spot; cilia brown mixed with ochreous along termen, white mixed with grey at tornus; underside pale grey except costal strigulae pale yellow and area of hindwing overlap posterior to $\mathrm{CuP}$ white. Hindwing upperside grey except area of forewing overlap anterior to $\mathrm{Sc}+\mathrm{R}_{1}$ white, cilia grey, with pale grey baseline; anal roll distinct; underside pale grey.

Male genitalia (Fig. 2b). Tegumen dorsally rounded, with lateral angular prominences. Socius plate-like, basal part broad, distal part slightly constricted, with apex concave at outer $1 / 3$ and forming two parts: the inner part large, triangular, densely haired, the outer part finger-like, with long hairs. Valva narrow; sacculus moderately wide, with sparse setae along outer and lower edge of basal cavity; cucullus elongate, uniform in width except slightly constricted at base and rounded at apex, the dorsal and ventral margins being subparallel. Aedeagus thick, cornuti consisting of a sheaf of short spines, 0.16 times as long as aedeagus.

Female. Unknown.

Distribution. China (Guizhou, Hunan).
Etymology. The specific name is derived from the Latin prefix sub- (= approximate) and parallelicus (= parallel), indicating the shape of dorsal and ventral margins of cucullus.

Remarks. According to Diakonoff (1973), males of the genus bear a hair pencil at base of their posterior tibia. In this study we found males of $P$. leechi ( $=$ P. obligata $)$ and the new species treated here bearing two separate hair pencils, which are different in length, thickness or color, but united at base. Concerning ground plan of costal strigulae, the description of other new species below follow Phaecasiophora supparallelica sp. n.

\subsubsection{Phaecasiophora (Phaecasiophora) levis sp. n. (Figs. 1c, 2c)}

Type material. Holotype کิ N, $110^{\circ} 25^{\prime}$ E), Guangxi Province, 1,100 m a.s.1., 20.IV.2002, leg. Shulian Hao and Huaijun Xue,

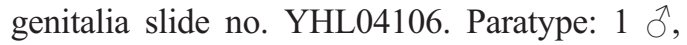
same data as holotype.

Diagnosis. This new species resembles $P$. attica (Meyrick) in shape of valva, but can be readily separated from the latter by the socius being somewhat quadrate and the aedeagus with cornuti composed of a small sheaf of sparse spines. In $P$. attica, the socius is triangular and cornuti consist of a sheaf of dense spines.

Description. Adult (Fig. 1c): Forewing length 9.0-9.6 mm. Vertex coarse, grayish brown, pale brown behind antenna. Antenna reaching 1/2 length of forewing, scape grayish brown, flagellum brown. Labial palpus ascending, slightly porrect, white, terminal segment and distal half of median segment pale grey. Thorax grayish brown, posterior portion and apex of tegula slightly pale brown. Legs white; lateral side of tarsi blackish brown, each subsegment white at apex; midleg with tibia covered by thornlike scales, lateral side brown, white in median side, posterior tibia strongly broadened by long and white scales, dusted with pale grey scales, and with two hair pencils from base, one white, thin and longer, the other pale grey, relatively thick and shorter. Forewing with costa a little arched; apex blunt; termen straight; upperside ground color grey, suffused with pale ochreous before tornus; costa with nine pairs of strigulae 
from base to $\mathrm{R}_{4}$, strigulae one and two pale grey, striae from them indistinct, strigulae three and four grey, striae from them extending backward to dorsum between $1 / 3$ and $2 / 3$ length, the distal five pairs of strigulae white, striae from strigulae five and six extending obliquely to tornus, discontinuous, strigulae eight and nine represented by a single marking, respectively, striae from strigulae seven and eight confluent, extending obliquely to termen between $\mathrm{M}_{1}$ and $\mathrm{M}_{2}$, stria from strigula nine reaching termen between $R_{5}$ and $\mathrm{M}_{1}$; basal fascia and subbasal fascia indistinct, broken by small grayish white spots, suffused with ochreous below costa; median fascia deep brown, suffused with ochreous between costa and base of $R_{3}$, broken by white spots on discal cell; postmedian fascia lunate, grey, suffused with ochreous, distal margin reaching termen; preterminal fascia narrow, indistinct; terminal fascia dark grey; cilia grey, with ochreous baseline; underside pale grey except costal strigulae pale yellow and area of hindwing overlap posterior to $\mathrm{CuP}$ white. Hindwing upperside grey except area of forewing overlap anterior to $\mathrm{Sc}+\mathrm{R}_{1}$ white, cilia grey; anal roll distinct; underside pale grey.

Male genitalia (Fig. 2c). Tegumen dorsally rounded, with lateral angular prominences. Socius densely with long hairs, broad, somewhat quadrate, broadened slightly to apex; apex projected strongly at middle and slightly at outer lateral angle. Valva with sacculus relatively narrow, sparsely setose along outer edge of basal cavity; cucullus constricted at base, with median part strongly dilated outward and 1.6 times as wide as base, rounded apically. Aedeagus thick; cornuti a small sheaf of short sparse spines, 0.26 times as long as aedeagus.

Female. unknown.

Distribution. China (Guangxi).

Etymology. The specific name is derived from the Latin levis (= smooth), to note the shape of distal edge of socius.

\subsubsection{Phaecasiophora (Phaecasiophora) curvicosta sp. n. (Figs. 1d, 2d)}

Type material. Holotype $\widehat{\jmath}$, Shangsi $\left(22^{\circ} 09^{\prime} \mathrm{N}\right.$, $\left.107^{\circ} 58^{\prime} \mathrm{E}\right)$, Guangxi Province, $510 \mathrm{~m}$ a.s.l., 6.IV.2002, leg. Shulian Hao and Huaijun Xue, genitalia slide no. YHL04261. Paratypes: $2 \hat{\jmath} \widehat{\jmath}$, Xinyi $\left(22^{\circ} 21^{\prime} \mathrm{N}, 110^{\circ} 56^{\prime} \mathrm{E}\right)$, Guangdong Province, 1,000 m a.s.1., 7.-13.VIII.2003, leg. Dandan Zhang.

Diagnosis. This new species resembles $P$. diluta Diakonoff in the male genitalia, but can be distinguished from the latter by the cucullus having the distal 2/3 broadened, and rounded apically, and the cornuti composed of a sheaf of sparse minute spines. In $P$. diluta Diakonoff, the cucullus is narrow and a little pointed apically, and the cornuti consist of a small sheaf of compact spines.

Description. Adult (Fig. 1d): Forewing length 9.1-9.3 mm. Vertex coarse, pale brown, blackish brown between and behind antenna. Antenna reaching 1/2 length of forewing, pale brown, with distal part grayish brown. Labial palpus ascending, with basal segment white; median segment with inner side white and lateral side pale ochreous, apex grayish brown; terminal segment grayish brown, small. Thorax brown; collar with basal part grayish brown, somewhat shinning blue and black, and apical part pale brown; tegula pale brown, sparsely scattered with brown scales. Legs with tarsi black-brown on lateral side, each subsegment white at apex; foreleg pale grey, with lateral side of tibia white; midleg white, tibia covered by thorn-like scales, lateral side blackish brown at base and apex; hind leg pale grey, with tibia strongly broadened by long and white scales, and carrying two hair pencils at base, one white, thin and longer, the other pale grey, thick and shorter. Forewing oblong; costa strongly convex, apex blunt, termen straight; upperside ground color grey; costa with nine pairs of strigulae from base to $\mathrm{R}_{4}$, strigulae one to four pale ochreous, striae from strigulae one and two extending to base of dorsum, indistinct; striae from strigulae three and four extending backward to 2/5-3/5 length of $\mathrm{Cu}$ vein, strigulae five to nine white, striae from strigulae five and six indistinguishable between costa and $\mathrm{R}_{2}$, covered by dense ochreous scales, stria from strigula five distinct below $\mathrm{R}_{2}$ and extending to tornus, interfered by postmedian fascia between base of $M_{1}$ and $M_{2}$, strigulae seven, eight and nine with striae confluent and extending to termen between $M_{1}$ and $M_{2}$; basal fascia and subbasal fascia black, broken by pale ochreous spots below costa; median fascia 
represented by a large black dot on costa and large umbrae between $\mathrm{M}$ stem and dorsum, the dot with center area occupied by two small ochreous dots and bordered by ochreous scales; postmedian fascia black, narrow, with proximal margin protruding between $M_{1}$ and $M_{3}$; terminal fascia a small ochreous dot; underside grey except costal strigulae pale yellow and area of hindwing overlap posterior to $\mathrm{CuP}$ white. Hindwing upperside grey; cilia pale grey, with grey baseline; anal roll distinct; underside grey.

Male genitalia (Fig. 2d). Tegumen dorsally subtriangular, lateral angular prominences small. Socius broad, distal half densely haired and constricted, with apex sunken at outer $1 / 3$, the inner part large, triangular and the outer part being a small lateral process. Valva with sacculus moderate in width, setae along outer edge of basal cavity long; cucullus slender, narrow at base, with distal $2 / 3$ broadened, equal in width, rounded apically. Aedeagus thick; cornuti composed of a sheaf of sparse minute spines.

Female. unknown.

Distribution. China (Guangxi, Guangdong).

Etymology. The specific name comes from the Latin prefix curv- (= curve) and costa, referring to the shape of costa in forewing.

\subsubsection{Phaecasiophora (Phaecasiophora) lushina sp. n. (Figs. 1e, 2e, 3b)}

Type material. Holotype $\widehat{\jmath}$, Lushi $\left(34^{\circ} 03^{\prime} \mathrm{N}\right.$, $\left.111^{\circ} 02^{\prime} \mathrm{E}\right)$, Henan Province, $1,700 \mathrm{~m}$ a.s.1., 20.VII.2000, leg. Dandan Zhang, genitalia slide no. ZAH03162. Paratype: 1 , , same data as holotype.

Diagnosis. This new species resembles $P$. pertexta (Meyrick) in the male genitalia, but can be distinguished from it by the socius being somewhat quadrate, and strongly projected at middle and outer lateral angle.

Description. Adult (Fig. 1e): Forewing length $9.0 \mathrm{~mm}$ in male, $9.3 \mathrm{~mm}$ in female. Male: face with smooth scales, white on lower half and pale brown on upper half. Vertex brown, with rough scales. Antenna damaged. Labial palpus ascending; median segment white, terminal segment pale grey, with a pointed apex. Thorax pale brown. Legs white, with lateral side of tarsi brown, each subsegment white at apex; median tibia with thorn-like scales, posterior tibia strongly broadened by long and silvery white scales, and with two white hair pencils, one longer and the other shorter. Forewing with costa gently arched; apex blunt; termen a little oblique; upperside ground color brown with slight pale ochreous suffusion; costa with nine pairs of white strigulae, strigulae one and two with striae extending to base of dorsum, indistinct, striae from strigulae three and four extending backward to dorsum between 2/5 length and midlength, stria from strigula five extending obliquely to tornus, broad, interfered by postmedian fascia between the base of $M_{1}$ and $M_{2}$, striae from strigulae six, seven and eight confluent and extending to termen between $M_{2}$ and $M_{3}$, stria from strigula nine extending to termen between $\mathrm{R}_{5}$ and $\mathrm{M}_{1}$; basal fascia and subbasal fascia dark brown and dusted with pale grey dots; median fascia dark brown, broken by pale grey spots, with a blackish brown spot at distal part of discal cell; postmedian fascia brown, proximal margin protruding medially; terminal fascia deep fuscous; underside pale grey except costa pale yellow and area of hindwing overlap posterior to CuP white. Hindwing upperside pale grey, white on area underlapping forewing; anal roll distinct; underside paler than that of forewing.

Female. Face smooth, white on lower half and brown on upper half. Vertex with rough scales, brown suffused with black brown. Antenna not reaching 1/2 length of forewing; scape brown; flagellum brown, darker at apical part. Labial palpus ascending, white, terminal segment grey, with a pointed apex. Thorax deep brown, sparsely scattered with ochreous scales. Legs white, with lateral side of tarsus in foreleg and midleg dark brown, each subsegment white at apex; foreleg with tibia dark brown, white at middle; midleg with tibia covered by thorn-like scales; posterior tibia with dense scales. Forewing upperside darker than that in the male, densely suffused with ochreous below costa and before apex; cilia brown, intermixed with ochreous, white at tornus, with deep brown baseline; underside grey except costal strigulae pale yellow and area of hindwing overlap posterior to $\mathrm{CuP}$ white. Hindwing upperside brown; cilia brown, with deep brown baseline; underside paler than that of forewing. 


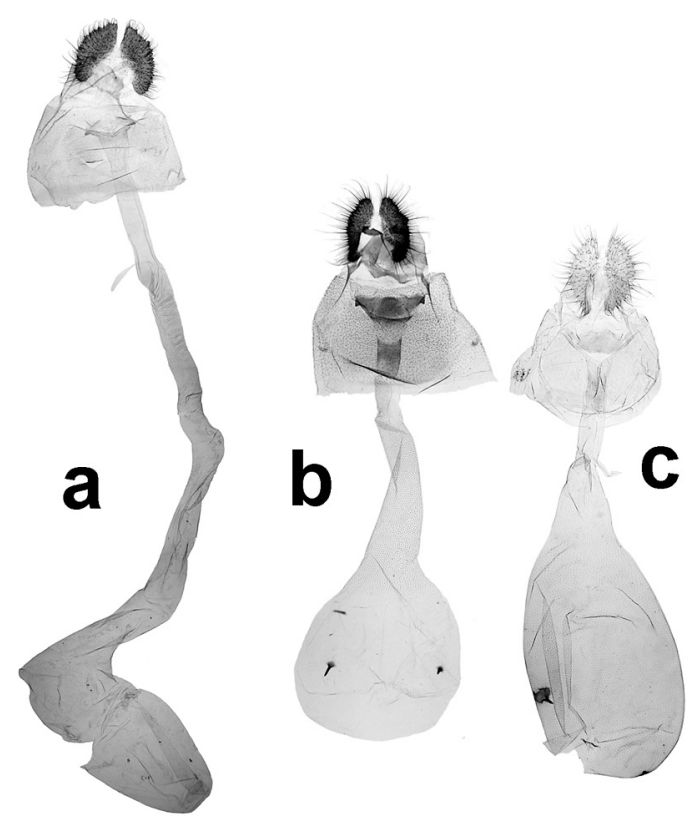

Fig. 3. Female genitalia of Phaecasiophora spp. - a. P. (P.) leechi Diakonoff (slide no. YHL04843). - b. P. (P.) lushina sp. n. (slide no. YHL04833). - c. P. (Megasyca) similithaiensis sp. n. (slide no. YHL04763).

Male genitalia (Fig. 2e). Tegumen dorsally rounded, with lateral angular prominences. Socius somewhat quadrate, projected at middle and lateral angle. Valva with sacculus slightly broadened medially, sparsely setose along outer edge of basal cavity; cucullus oblong and broad, with median part slightly expanded and 1.3 times as wide as base. Aedeagus thick; cornuti consisting of a sheaf of short spines, 0.23 times as long as aedeagus.

Female genitalia (Fig. 3b). Papillae anales narrow. Anterior and posterior apophyses thin, equal in length. Ostium broad. Lamella antevaginalis weakly sclerotized. Lamella postvaginalis broad, somewhat semicircular, aciculate, posterior margin with a lateral triangular prominence directed downwards. Ductus bursae posteriorly encircled by short colliculum, anteriorly granulate, gradually dilated. Corpus bursae oval, slightly granulated with two small, horned, densely granulated signa.

Distribution. China (Henan).

Etymology. The specific name is from the type locality-Lushi, Henan Province.

\subsection{Subgenus Megasyca Dianonoff, 1959}

Megasyca Diakonoff, 1959: 171.

Type species: Phaecasiophora fernaldana Walsingham, 1900 (by original designation)

Species of this subgenus are usually paler in color than those of Phaecasiophora s. str. They are characterized by male genitalia with socius enlarged and sclerotized, pointed apically; tegumen usually broad; cucullus with base often dilated and densely bristled.

\subsubsection{Phaecasiophora (Megasyca) cornigera Diakonoff, 1959}

Phaecasiophora (Megasyca) cornigera Diakonoff, 1959: 180, plate 5, figure 16, plate 7, figure 22 ( $\lesssim, q$ genit., India: Assam).

Material examined. China: 4 ふ઼่, Mt. Wuyi (265' $4^{\prime}$, $116^{\circ} 42^{\prime}$ E), Fujian Province, 1,000 m a.s.1., 26.V.2004, leg. Haili Yu. 1 đo, Mt. Mao'er $\left(25^{\circ} 53^{\prime} \mathrm{N}, 110^{\circ} 25^{\prime} \mathrm{E}\right)$, Guangxi Province, 1,100 $\mathrm{m}$ a.s.1., 20.IV.2002, leg. Shulian Hao and Huaijun Xue. 1 đo, Tianquan $\left(30^{\circ} 06^{\prime} \mathrm{N}, 102^{\circ} 46^{\prime}\right.$ E), Sichuan Province, 1,300 m a.s.1., 29.VII. 2004, leg. Yingdang Ren. 1 đ̊, Daozhen (29³2' N, 107²0' E), Guizhou Province, 1,420 m a.s.1., 22.VII.2004, leg. Shulian Hao.

Distribution. China (Fujian, Guangxi, Sichuan, Guizhou, Taiwan), Vietnam, Burma, Thailand, India.

Remarks. Diakonoff (1959) described two subspecies of this species, Phaecasiophora (Megasyca) cornigera burmensis from North Burma, and P. (M.) cornigera cornigera from Assam, India. Kawabe et al. (1992) recorded the nominal subspecies from Taiwan and we collected it from the Chinese Mainland in this study. The species is characterized by the long and slender cucullus with a long thorn at base.

\subsubsection{Phaecasiophora (Megasyca) fernaldana} Walsingham, 1900

Phaecasiophora fernaldana Walsingham, 1900: 135 ( ${ }^{\top}$,, , Japan, Corea)

Phaecasiophora (Megasyca) fernaldana: Diakonoff, 1959: 179, plate 4, figure 12, plate 
6, figures $18-20$ ( $\hat{\jmath},+$ genit. $)$

Phaecasiophora (Megasyca) latior Diakonoff, 1959: 180, plate IV, figure 13 ( 9 genit., Borneo)

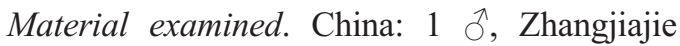
(2949’ N, 110²6’ E), Hunan Province, 650 m a.s.1., 7.VIII.2001, leg. Houhun Li and Xinpu

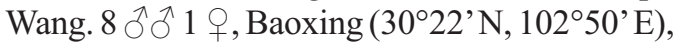
Sichuan Province, 1,600 m a.s.1., 3.VIII.2004, leg. Yingdang Ren. 1 ऽ, Tianquan $\left(30^{\circ} 06^{\prime} \mathrm{N}\right.$, $102^{\circ} 46^{\prime}$ E), Sichuan Province, 1,300 m a.s.1., 29.VII.2004, leg. Yingdang Ren. 1 Ĵ, Chishui

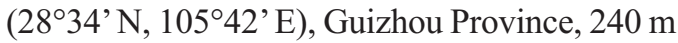
a.s.1., 21.IX.2000, leg. Haili Yu.

Distribution. China (Anhui, Hunan, Sichuan, Guizhou, Taiwan), Korea, Japan, Indonesia, Borneo, Russia.

Remarks. This species is widely distributed in East Asia and South-east Asia. Liu \& Li (2002) recorded this species from Anhui Province and gave the illustrations of adults and genitalia. It is characterized by having the ear-like socius and the cucullus with a strongly projecting and semicircular base.

\subsubsection{Phaecasiophora (Megasyca) walsinghami Diakonoff, 1959}

Phaecasiophora (Megasyca) walsinghami Diakonoff, 1959: 179, plate 4, figure 14, plate 6, figures 20-21 ( $\hat{0}$, o genit., Indonesia: West Java)

Material examined. China: $1 \curvearrowright 1$, Mt. Longwang (30 $23^{\prime}$ N , $119^{\circ} 24^{\prime}$ E), Zhejiang Province, 26.VII.1996, leg. Hong Wu. 1 đo, Mt. Tianmu (30²6’ N, 119³4' E), Zhejiang Province, $500 \mathrm{~m}$ a.s.1., 16.VIII.1999, leg. Houhun Li. 1 q, Mt. Jiuhua $\left(30^{\circ} 23^{\prime} \mathrm{N}, 117^{\circ} 48^{\prime} \mathrm{E}\right)$, Anhui Province, 9.VIII.2004, leg. Jiasheng $\mathrm{Xu}$ and Jialiang Zhang. 1 o, Xiangtan $\left(27^{\circ} 52^{\prime} \mathrm{N}, 112^{\circ} 53^{\prime} \mathrm{E}\right)$, Hunan Province, 30.VII.2004, leg. Yunli Xiao. 1 đ, Shangsi (2209' N, $107^{\circ} 58^{\prime}$ E), Guangxi Province, $770 \mathrm{~m}$ a.s.1., 3.IV.2002, leg. Shulian Hao and Huaijun Xue. 2 ふふふ,, Mt. Fanjing $\left(27^{\circ} 55^{\prime} \mathrm{N}\right.$, $\left.108^{\circ} 41^{\prime} \mathrm{E}\right)$, Guizhou Province, 1,300 $\mathrm{m}$ a.s.1., 3.VIII.2001, leg. Houhun Li and Xinpu Wang.

Distribution. China (Zhejiang, Anhui, Hunan, Guangxi, Guizhou), Indonesia, Thailand.
Remarks. Diakonoff (1959, 1973) discussed this species in detail. It is closely related to $P$. fernaldana in the genitalia, but differs by the cucullus being longer and narrower, with the base oblong-oval, and the sterigma slightly concave at posterior edge. In P. fernaldana, the cucullus is broad, and the sterigma is rounded at posterior edge. This species is recorded for the first time from China.

\subsubsection{Phaecasiophora (Megasyca) obraztsovi Diakonoff, 1973}

Phaecasiophora (Megasyca) obraztsovi Diakonoff, 1973: 124, figures 239 (ठ̋ genit., Japan), 240-241 ( 9 genit.)

Material examined. China: 19 ふえた 5 ㅇ, Mt. Tianmu (30²6' N, 119³4' E), Zhejiang Province, 350-1,500 $\mathrm{m}$ a.s.1., 15.-19.VIII.1999, leg. Houhun Li. sia.

Distribution. China (Zhejiang), Japan, Rus-

Remarks. This species resembles Psilacantha pryeri (Walsingham) in appearance. The main difference between the two species lies in the hind tibia of male, which is densely covered with a broad tuft of long scales in P. obraztsovi. The two species can also be readily separated from each other by the genital structures. This species is recorded for the first time from China.

\subsubsection{Phaecasiophora (Megasyca) pyragra Diakonoff, 1973}

Phaecasiophora (Megasyca) pyragra Diakonoff, 1973: 122-123, figure 185 (ô genit., China: Hainan)

Material examined. China: $1 \hat{\jmath}$, Mt. Jiuwandashan $\left(25^{\circ} 22^{\prime} \mathrm{N}, 108^{\circ} 37^{\prime} \mathrm{E}\right)$, Guangxi Province, 620 m a.s.1., 25.VIII.2001, leg. Huaijun Xue.

Distribution. China (Guangxi, Hainan).

Remarks. Diakonoff (1973) described this species from Hainan Province. Liu \& Li (2002) reported it from the same locality, and we also found it in Guangxi Province. This species is typically represented by the very long aedeagus, which is well sclerotized and has large dentations at apex. 


\subsubsection{Phaecasiophora (Megasyca) \\ similithaiensis sp. n. (Figs. 1f, 2f, 3c)}

Type material. Holotype $\widehat{\jmath}$, Sangzhi (29²3' N, $\left.110^{\circ} 13^{\prime} \mathrm{E}\right)$, Hunan Province, 1,250 m a.s.l., 13.VIII.2000, leg. Houhun Li and Xinpu Wang, genitalia slide no. YHL04314. Paratypes: 6 ふึ 1 + , same data as holotype.

Diagnosis. This species is similar to Phaecasiophora thaiensis Kawabe and Sycacantha diakonoffi Kawabe in the male genitalia, but can be distinguished from them by the following characters: valva broader and shorter than those in the latter species, cucullus distinctly constricted at middle and broadened in distal half. This species also resembles $P$. astrosema (Meyrick) in the male genitalia, but the cucullus is more slender and longer, and the socius is smaller in the latter species than those in this new species.

Description. Adult (Fig. 1f): Forewing length 6.9-7.9 $\mathrm{mm}$ in males, $7.5 \mathrm{~mm}$ in female. Vertex pale brown, with rough scales. Antenna reaching $1 / 2$ length of forewing, pale brown. Labial palpus ascending, white; median segment not dilated, terminal segment pointed apically. Thorax pale brown, tegula with base deep brown. Legs white; foreleg with outer side of tibia and tarsus deep brown, middle of tibia white, each subsegment of tarsus white at apex; midleg with tibia covered by thorn-like scales, outer side pale brown, tarsus with outer side brown; male posterior tibia broadened, covered with long silvery white scales, and with two hair pencils at base, one pale yellow and shorter, and the other grey and longer; female with posterior tibia white and not broadened. Abdomen pale grey. Forewing with costa gently arched, apex blunt, termen straight; upperside ground color pale grey suffused with pale ochreous; costa with nine pairs of pale yellow strigulae, strigulae one and two indistinct, striae from them extending posteriorly to the base of $2 \mathrm{~A}$, respectively, strigulae three and four represented by a single marking, respectively, striae from them extending backward to dorsum between 1/4 length and midlength, indistinct, strigulae five and six confluent, striae from them broad, extending obliquely to tornus, strigulae seven and eight represented by a single marking, respectively, indistinct, striae from strigulae seven, eight and nine confluent and extending to
$\mathrm{R}_{5}$ at termen; basal fascia and subbasal fascia indistinct, pale brown, broken by white dots; median fascia indicated by a brown dot on costa; postmedian fascia brown, with posterior margin reaching distal part of $\mathrm{M}_{2}$, distal margin reaching termen; terminal fascia a small brown spot; cilia grey along termen between apex and $\mathrm{M}_{2}$, pale ochreous below; underside pale grey, paler on area of hindwing overlap posterior to $\mathrm{CuP}$. Hindwing upperside pale grey to grey, white on area underlapping forewing, cilia pale grey; anal roll distinct in males; underside concolorous with that of forewing.

Male genitalia (Fig. 2f). Tegumen dorsally triangular, lateral angular prominences large. Socius large and triangular, apically pointed and densely haired. Valva with sacculus short and broad, bearing long setae along outer edge of basal cavity; cucullus long, broadened strongly in basal half, constricted at middle, broadened in distal half, rounded at apex. Aedeagus short and thick, with length 2.2 times of its breadth and 0.22 times of valva in length; cornuti consisting of a sheaf of long scales, less than half times of aedeagus in length.

Female genitalia (Fig. 3c). Papillae anales fan-shaped. Apophyses posterior short, a little longer than half of apophyses anterior. Lamella antevaginalis large, with posterior edge Vshaped; lamella postvaginalis weakly sclerotized, broad and naked. Ostium inverted-triangular. Ductus bursae short, encircled with short, weakly sclerotezed colliculum, anteriorly densely punctulated and broadened; anterior half broadened. Corpus bursae long-oval, densely granulated, with two signa, one large and sharply cornute, and the other very small.

Distribution. China (Hunan).

Etymology. This specific name is derived from the Latin prefix simil- $(=$ similar $)$ and thaiensis, referring to the similarity of this new species to $P$. thaiensis Kawabe.

Acknowledgments. We thank Prof. Hong Wu, Zhejiang Forestry University, Prof. Zizhong Li, Guizhou University, Prof. Xiaocheng Shen, Henan Academy of Agricultural Science, and Mr. Jiashe Wang, Head of Wuyi Nature Reserves, China, for field work assistance. This research was financially supported by the National Natural Science Foundation of China for the Special Program and the Innovation Project of Chinese Academy of Sciences (BBG-0401) 


\section{References}

Baixeras, J. 2002: An overview of genus-level taxonomic problems surrounding Argyroploce Hübner (Lepidoptera: Tortricidae), with description of a new species. Ann. Entomol. Soc. Am. 95 (4): 422-431.

Brown, R. L. \& Powell, J. 1991: Description of a new species of Epiblema (Lepidoptera: Tortricidae: Olethreutinae) from coastal redwood forests in California with an analysis of the forewing pattern. - Pan-Pacific Entomologist 67 (2): 107-114.

Byun, B. K., Bae, Y. S. \& Park, T. 1998: Illustrated Catalogue of Tortricidae in Korea. - In: Park, K. T. (ed.), Insects of Korea Series [2]. 317 pp.

Clarke, J. F. G. 1958: Catalogue of Type Specimens of Microlepidoptera in the British Museum (Natural History) described by Edward Meyrick 3. - British Museum (Natural History), London. 600 pp.

Diakonoff, A. 1959: Entomological results from the Swedish expedition 1934 to Burma and British India. Microlepidoptera II. — Arkiv för Zoologi, Ser. 2 (12): 165-182.

Diakonoff, A. 1966: Notes on the Olethreutini and some Tortricinae from the Papuan Region in the Meyrick collection, British Museum, with selection of lectotypes (Lepidoptera, Tortricidae). — Zool. Verh. 85: 186, figs. 1-86, pl. 1.

Diakonoff, A. 1973: The south Asiatic Olethreutini (Lepidoptera, Tortricidae). — Zool. Monogr. Rijksmus Nat. Hist. 1. 700 pp. +15 pls.

Diakonoff, A. 1983a: Tortricidae from Madagascar part 2. Olethreutinae, 2 (Lepidoptera). - Annals Soc. Ent. Fr. (N. S.) 19 (3): 291-310, 29 figs., 1 réf.

Diakonoff, A. 1983b: Tortricidae from Atjeh, Northern Sumatra (Lepidoptera). — Zool. Verh. 204: 1-132.

Fernald, C. H. 1908: The genera of the Tortricidae and their types. Carpenter \& Morehouse, Amherst. 68 pp.

Grote, A. R. 1873: Contributions to a knowledge of North American Moths. — Bull. Buffalo Soc. Nat. Sci. I: 73 94, pl. 2.

Heinrich, C. 1926: Revision of North American moths of the subfamilies Laspeyresiinae and Olethreutinae. U. S. Nat. Mus. Bull. 132: 1-216, pls. 1-76.

Heinrich, C. 1931: Notes on and Descriptions of some American Moths. - Proc. U. S. Nat. Mus. 79 no. 2879: 13.

Kawabe, A. 1982: Tortricidae. — In: Inoue, H. et al. (eds.), Moths of Japan 1: 62-151, 2: 158-181, pls. 14-30, 279-294. Kodansha, Tokyo. 966 pp.

Kawabe, A. 1986: Notes on the Tortricidae (Lepidoptera) from Taiwan, 2. - In: Ueno, S. I. (ed.), Entomological papers presented to Yoshihiko Kurosawa on the occasion of his retirement: 77-84. Coleopterists' Association of Japan, Tokyo. 342 pp.

Kawabe, A. 1987: Records and descriptions of the subtribe Sycacanthae (Lepidoptera: Tortricidae) from Thiland.
- Microlepidoptera of Thailand (1): 61-68.

Kawabe, A. 1989: Records and Descriptions of the Subfamily Olethreutinae (Lepidoptera: Tortricidae) from Thailand. - Microlepidoptera of Thailand 2: 23-82.

Kawabe, A. 1993: Notes on the Tortricidae (Lepidoptera) from Taiwan 6. - Tinea 13 (21-29): 227-239.

Kawabe, A., Komai, F. \& Razowski, J. 1992: Tortricoidea. - In: Heppner J. B. \& Inoue, H. (eds.), Lepidoptera of Taiwan Vol. 1 part 2. Checklist: 103-109.

Kuznetsov, V. I. 1997: New species of Tortricid moths of the subfamily Olethreutinae (Lepidoptera, Tortricidae) from the South of Vietnam. - Ent. Obozr. 76 (4): 797-812. [In Russian.]

Kuznetsov, V. I. 2001: Tortricidae. — In: Ler, P. A. [ed.], Key to the insects of Russian Far East. Vol. V. Trichoptera and Lepidoptera. Pt 3: 11-472. Dal'nauka, Vladivostok. 622 pp. [In Russian.]

Li, H. H. \& Zheng, Z. M. 1996: Methods and techniques of specimens of Microlepidoptera. - Journal of Shaanxi Normal University (Natural Science Edition) 24 (3): 63-70. [In Chinese.]

Liu, Y. Q. \& Li, G. W. 2002: Fauna Sinica Insecta Vol. 27 Lepidoptera: Tortricidae. - Science Press, Beijing. 463 pp., 138 pls. [In Chinese.]

Meyrick, E. 1907: Discriptions of Indian Micro-Lepidoptera. I. — Journ. Bombay Nat. Hist. Soc. 16: 580619.

Meyrick, E. 1909: Descriptions of Indian Micro-Lepidoptera. X. - Journ. Bombay Nat. Hist. Soc. 19: 582607.

Meyrick, E. 1920: Exotic Microlepidoptera 2: 351.

Meyrick, E. 1931: Exotic Microlepidoptera 4: 138.

Meyrick, E. 1935: — In: Caradja, A. \& Meyrick, E., Materialien zu einer Microlepidopteren - Fauna der Chinesischen Provinzen Kiangsu, Chekiang und Hunan. Friedländer \& Sohn, Berlin. 96 pp., 3 pls.

Meyrick, E. 1938: — In: Caradja, A. \& Meyrick, E. (eds.), Materialien zu einer Microlepidopterenfauna des Yülingshanmassivs (Provinz Yünnan). Dt. Iris, 52: 129.

Razowski, J. 1989: The genera of Tortricidae (Lepidoptera). Part II: Palaearctic Olethreutinae. - Acta Zool. Cracov. 32 (7): 107-328, 576 figs.

Robinson, G. S., Sattler, K., Shaffer, M., Tuck, K., R. and Allen, M. G. 1995: Microlepidoptera and Pyraloidea of Nepal - a checklist and bibliography. - Tinea. 14 (Suppl. 2): 150-181.

Walker, F. 1863: List of the specimens of Lepidopterous insects in the collection of the British Museum, part 28, Tortricites \& Tineites: i-iv, 287-561. — London.

Walsingham, L. 1891: The African Microlepidoptera. The Transactions of the Entomological Society of London: 63-132, pls. 3-7.

Wasingham, L. 1900: Asiatic Tortricidae. - Ann. Mag. Nat. Hist. (Ser. 7) 6: 121-137, 234-243. 